\title{
Recombinant DNA studies on stored necropsy brain samples from patients with Huntington's chorea
}

\author{
MEENA UPADHYAYA, GP REYNOLDS, ${ }^{*}$ PS HARPER
}

From the Section of Medical Genetics, University of Wales College of Medicine, Cardiff and the ${ }^{*}$ Medical Research Council Neurochemical Pharmacology Unit, Brain Tissue Bank, Addenbrooke's Hospital, Cambridge

SUMMARY An analysis of deoxyribonucleic acid (DNA) in deep frozen brain samples taken from 100 patients with Huntington's chorea after death showed undegraded DNA in 44 cases. Of these, 16 were analysed with G8, a recombinant DNA probe, linked to the Huntington's chorea locus. In all cases unambiguous Southern blots were obtainable. No correlation between the yield of DNA and the principal storage factors was observed. The use of stored brain tissue obtained after death from patients with Huntington's chorea should be considered when analysis of DNA is needed for predictive studies, but DNA should preferably be isolated from the tissue before storage as degradation in these samples can occur.

Huntington's chorea is a serious, progressive brain disorder following autosomal dominant inheritance and is generally of late onset. Close genetic linkage has recently been found between Huntington's chorea and a polymorphic DNA probe G8 on chromosome $4 .^{1}$

Considerable attention has been devoted to the careful preservation of brain tissue of affected patients obtained after death as part of studies to define specific neurochemical abnormalities in Huntington's chorea. Brain tissues from patients with the disease have been stored at $-70^{\circ} \mathrm{C}$ over the past 10 years at the Medical Research Council brain bank in Cambridge, England, and provided the source of the material used in this study. The object of this study was to evaluate the usefulness of these samples for the study of DNA polymorphisms in relation to Huntington's chorea and other genetic disorders.

\section{Subjects and methods}

Brain samples (100-400 mg wet weight) from 100 patients with Huntington's chorea were analysed, the tissue being taken from the frontal cortex. About $300 \mathrm{mg}$ of tissue was homogenised on ice in 1 $\mathrm{ml}$ sterile buffer ( $10 \mathrm{mM}$ Tris, $1 \mathrm{mM}$ edetic acid, 150 $\mathrm{mM}$ sodium chloride, $0.5 \%$ SDS, $\mathrm{pH} 10.5)$. Proteinase $\mathrm{K}(100 \mu \mathrm{l} ; 10 \mathrm{mg} / \mathrm{ml})$ and SDS $(50 \mu \mathrm{l} ; 10 \%)$ were added to the homogenate, and the solution was incubated at $56^{\circ} \mathrm{C}$ for three hours. After extraction

Accepted for publication 19 June 1985 with redistilled phenol (BRL) and twice with chloroform the DNA was recovered by ethanol precipitation at $-70^{\circ} \mathrm{C}$ for one hour and redissolved in TE buffer (10 mM Tris, $1 \mathrm{mM}$ edetic acid, pH 8.0). Ribonuclease was then added and the reaction mixture incubated at $37^{\circ} \mathrm{C}$ for one hour. The DNA in the resulting solution was extracted with phenol and twice with chloroform and ethanol precipitated. Purity of this DNA was assessed spectrophotometrically. Total DNA $(0.5 \mu \mathrm{g})$ was run on $1 \%$ agarose gel for two hours at 70 volts. Degradation of the DNA was indicated by the presence of a smear on the gel.

Undegraded DNA from 16 samples was studied with probe G8, ${ }^{1}$ which is known to be linked to the Huntington's chorea gene. DNA was digested with Hind III and run on $0.8 \%$ agarose gel in TBE buffer ( $89 \mathrm{mM}$ Tris $\mathrm{pH} 8,89 \mathrm{mM}$ sodium borate, $2 \mathrm{mM}$ sodium edetic acid) for at least 18 hours. The gel was exposed to ultra violet light for five minutes and Southern blots were obtained ${ }^{2}$ and hybridised with a subclone (pk 082) of probe G8 that shows a Hind III restriction fragment length polymorphism with bands at $17 \cdot 5,15,4.9$, and $3.7 \mathrm{~kb} .^{1}$ DNA was also digested with EcoR1 and run on $0.8 \%$ agarose gel in TBE buffer. The Southern blots were hybridised

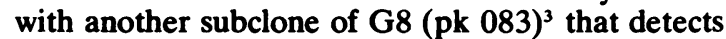
an EcoR1 polymorphism with bands at 14.5 and 9.1 $\mathrm{kb}$. Sixteen samples were also hybridised with the $X$ linked probes DXYS1 ${ }^{4}$ and L1.28.5 (DXYS1 also detects a Y chromosome specific sequence.)

DNA was extracted from two fresh necropsy 
brain samples from patients with Huntington's chorea and examined in a similar manner to the stored brain samples.

\section{Results}

Undegraded DNA was present in 44 of the 100 samples. The yield of DNA from the undegraded samples ranged from 0.05 to $0.72 \mu \mathrm{g} / \mathrm{mg}$ wet weight of tissue (mean $0.23 \mu \mathrm{g} / \mathrm{mg}$ wet weight of tissue).

Several variables (Table) were studied that could be relevant to the yield of DNA, in particular storage time and delay until necropsy, but no significantly positive correlations were observed.

Satisfactory G8 typing was achieved (Fig.) in all samples with undegraded DNA chosen for analysis; similar satisfactory typing was seen for the two $\mathrm{X}$ chromosome probes, already in use in our laboratory for studies on X linked disorders. DNA from the two fresh brain samples was satisfactorily typed with the probes used in this study.

\section{Discussion}

When using linked genetic markers to predict a disorder such as Huntington's chorea it is essential to know the genotype of an affected subject in the
Correlation between yield of DNA ( $\mu \mathrm{g} / \mathrm{mg}$ wet weight) and relevant variables

\begin{tabular}{llcl}
\hline Variables & Range & Meah (SD) & $\begin{array}{l}\text { Correlation with } \\
\text { yield of DNA }(r)\end{array}$ \\
\hline $\begin{array}{l}\text { Yield of DNA } \\
\text { ( } \mu \text { g/mg wet weight) }\end{array}$ & $0.05-0.72$ & $0.23(0.13)$ \\
$\begin{array}{l}\text { Age of patient } \\
\text { (years) }\end{array}$ & $6-85$ & $52.2(15.5)$ & 0.096 \\
$\begin{array}{l}\text { Storage time (years) } \\
\text { Delay until necropsy } \\
\text { (hours) }\end{array}$ & $0-8$ & $6.0(1.38)$ & 0.166 \\
$\begin{array}{l}\text { Duration of illness } \\
\text { (years) }\end{array}$ & $0.75-99$ & $41.7(33.0)$ & 0.115 \\
\hline
\end{tabular}

parental generation. As these subjects may already have died the possibility of using stored tissue, such as that of the brain, is of considerable importance.

This study clearly indicates that it is possible to isolate undegraded DNA from a proportion of stored frozen brains from patients with Huntington's chorea and to type specific DNA polymorphisms, including those shown by the probe G8, which are closely linked to Huntington's chorea. The retention of necropsy brain tissue from patients with Huntington's chorea is therefore advocated for any further predictive studies. As more than $50 \%$ of DNA samples are degraded in this stored tissue, however, we o suggest that DNA should preferably be isolated ans

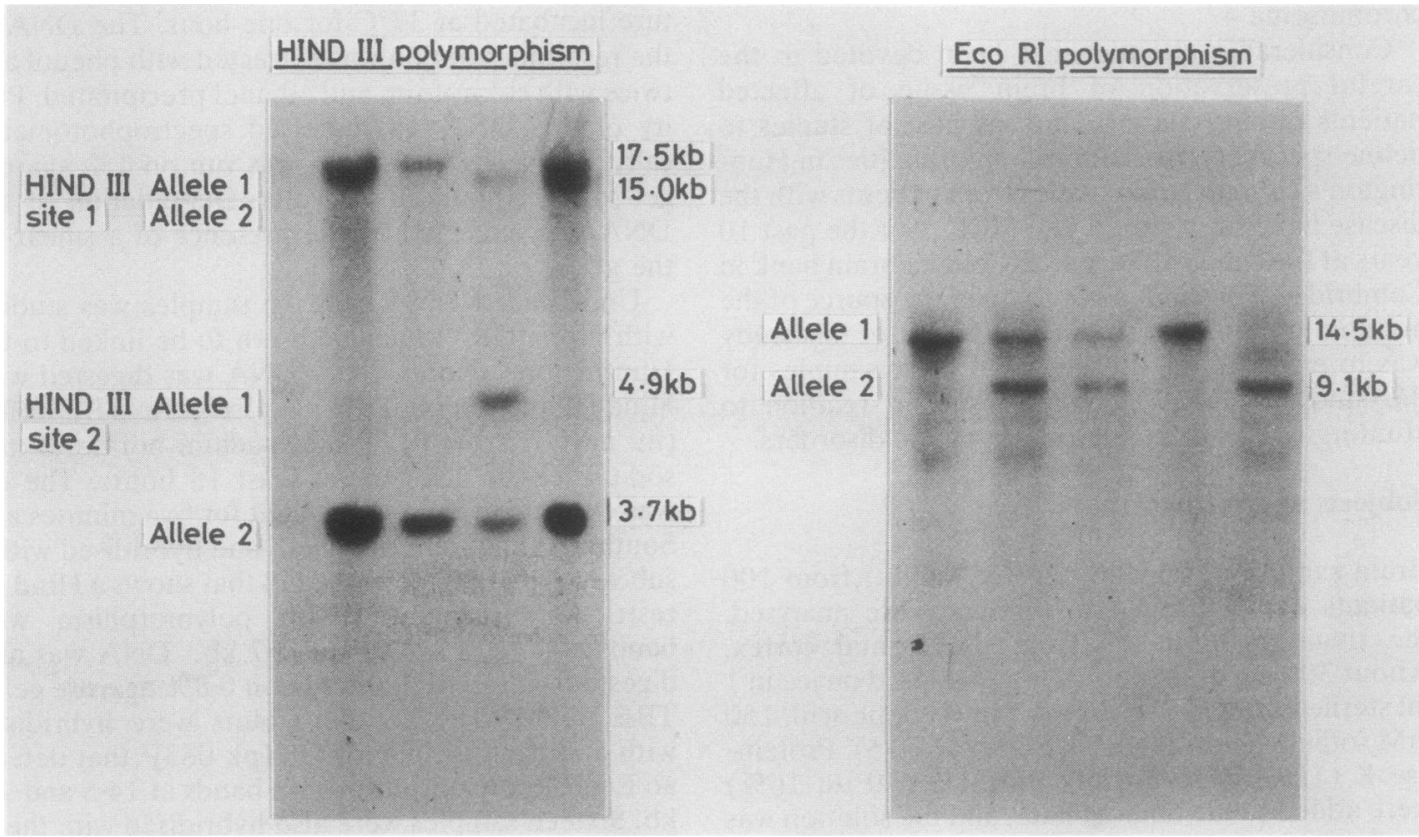

(a), (b) Brain DNA hybridised to probe pK082 (subclone of G8) (left) showing Hind III polymorphism with bands at 17.5, $15,4.9$, and $3.7 \mathrm{~kb}$. DNA from brain typed with probe pK083 (subclone of G8) (right), showing EcoR1 polymorphism with band at 14.5 and $9 \cdot 1 \mathrm{~kb}$. 
the quality tested before storage and that stored brain tissue should not be relied on exclusively.

Whenever possible it is advisable to store DNA isolated from venous blood samples taken from the patient (and key relatives) during life, and this is the regular practice in our unit. Stored brain and other tissue samples, however, still remain a valuable source of DNA for linkage analysis after death.

We found no clear correlation between the yield of DNA and the most obvious storage factors (duration of storage and delay until necropsy). The quality of DNA (whether degraded or non-degraded) was also not related to these factors, or to duration of the illness or age at death. Although all the samples were taken from the frontal cortex, their relatively small size and the known morphological heterogeneity of brain tissue could have accounted for some of the variation in the quality and yield of DNA. There is also the possibility that primary degeneration of brain tissue related to disease could have contributed towards variable DNA degradation.

We gratefully acknowledge the support of the Medical Research Council and the Association to Combat Huntington's chorea. We thank Dr J Gusella, Dr
D Page, and Professor P Pearson for the gifts of probes G8, DXYS1, and L1.28, respectively; Dr D Shaw and Miss Sandra Youngman for advice on probe analysis; and Drs PM Conneally and E Bird for their helpful suggestions.

\section{References}

' Gusella JF, Wexler NS, Conneally PM, et al. A polymorphic DNA marker genetically linked to Huntington's disease. Nature 1983;306: 234-8.

${ }^{2}$ Southern EM. Detection of specific sequences among DNA fragments separated by gel electrophoresis. J Mol Biol 1975;98:503-17.

${ }^{3}$ Gusella JF, Tanzi RE, Anderson MA, et al. DNA markers for nervous system diseases. Science 1984;225:1320-6.

${ }^{4}$ Page D, Demartinville B, Barker D, et al. Single copy sequence hybridises to polymorphic and homologous loci on human $\mathrm{X}$ and $\mathrm{Y}$ chromosomes. Proc Natl Acad Sci (USA) 1982; 79: 5352-6.

s Davies KE, Pearson PL, Harper PS, et al. Linkage analysis of two cloned DNA sequences flanking the Duchenne muscular dystrophy locus on the short-arm of the human $\mathrm{X}$ chromosome. Nucleic Acids Res 1983;11:2303-12.

Requests for reprints to: Professor PS Harper, Section of Medical Genetics, Department of Medicine, University of Wales College of Medicine, Heath Park, Cardiff CF4 4XN, Wales. 